Gerhard Ernst

Einführungskurs Italienisch 

Gerhard Ernst

\section{Einführungskurs Italienisch}

11., überarbeitete Auflage

Max Niemeyer Verlag Tübingen 1998 
1. Auflage 1970

2. Auflage 1972

3. Auflage 1973

4. Auflage 1975

4. Auflage, 2. Druck 1977

5., überarb. Auflage 1978

5. Auflage, 2. Druck 1980

6. Auflage 1981

7. Auflage 1983

8. Auflage 1985

9., überarb. u. enw. Auflage 1988

10., durchgesehene Auflage 1991

Zu diesem Kurs sind lieferbar:

Übungscassetten zum Lehrbuch

(Übungen des Lehrbuchs auf 4 Kassetten)

Die Deutsche Bibliothek - CIP-Einheitsaufnahme

Ernst Gerhard:

Einfuihrungskurs Italienisch / Gerhard Ernst. - 11. überarb. Aufl. - Tübingen : Niemeyer, 1998

ISBN 3-484-50052-2

(C) Max Niemeyer Verlag GmbH, Tübingen 1998

Das Werk einschließlich aller seiner Teile ist urheberrechtlich geschützt. Jede Verwertung außerhalb der engen Grenzen des Urheberrechtsgesetzes ist ohne Zustimmung des Verlages unzulässig und strafbar. Das gilt insbesondere für Vervielfältigungen, Übersetzungen, Mikroverfilmungen und die Einspeicherung und Verarbeitung in elektronischen Systemen.

Printed in Germany.

Gedruckt auf alterungsbeständigem Papier.

Satz: ScreenArt GmbH, Wannweil

Druck und Bindung: J. Ebner Graphische Betriebe, Ulm 